\title{
Oil Revenue, Public Spending and Economic Growth Relationships in Nigeria
}

\author{
Omo Aregbeyen $^{1} \&$ Bashir Olayinka Kolawole ${ }^{2}$ \\ ${ }^{1}$ Department of Economics, University of Ibadan, Ibadan, Nigeria \\ ${ }^{2}$ Department of Economics, Lagos State University, Ojo, Lagos, Nigeria \\ Correspondence: Bashir Olayinka Kolawole, Department of Economics, Lagos State University, P.M.B 0001, \\ LASU Post Office, Ojo, Lagos State, Nigeria. Tel: 234-806-663-7927. E-mail: kolawolebashir@gmail.com
}

\author{
Received: March 11, 2015 Accepted: March 30, 2015 Online Published: May 28, 2015 \\ doi:10.5539/jsd.v8n3p113 URL: http://dx.doi.org/10.5539/jsd.v8n3p113
}

\begin{abstract}
This study examined the relationships among oil revenue, government spending, and economic growth in Nigeria. By implication, it investigated whether oil revenue impacted on government spending, as well as on economic growth in the country over the period from 1980 to 2012. Time series data were analyzed using econometric techniques which included Ordinary Least Square (OLS), cointegration, Vector Error Correction Model (VECM), and Granger causality to determine the direction of causality and the magnitude of impacts of the variables. Findings from the analysis revealed that oil revenue Granger caused both of total government spending and growth, while there was no-causality between government spending and growth in the country. The study therefore suggested that government should increase spending on capital projects as well as intensify efforts at increasing output in the oil sub-sector in order to boost economic growth in Nigeria.
\end{abstract}

Keywords: causality, co-integration, economic growth, Nigeria, oil revenue, public spending,

\section{Introduction}

In recent time, the international per barrel price of crude oil dropped drastically from about USD 110 from the last quarter of 2014 to almost USD 40 in January 2015. Consequently, Nigeria's foreign reserve was depleted from over USD 42 billion to about USD 30 billion. By implication, a further reduction in the international per barrel price of crude oil would spell a continuous fall in the aggregate revenue profile of Nigeria, as well as its public expenditure and economic growth. Ordinarily, a persistent increase in the function of the state where new functions are continually being undertaken and old ones are performed more efficiently, there is tendency for increase in public spending (see Wagner, 1883). But then, increasing public expenditure is dependent on a greater affluence of the state (see Cameron, 1978), and an increased public expenditures in tradable sectors presents the opportunity to make oil revenue an engine of national development (Kablan, Leoning \& Tanaka, 2014). In fact, oil revenues are the main source of financing government expenditures and imports of goods and services, as increasing oil prices over the years has boosted public expenditures on social and economic infrastructure (see Hamdi \& Sbia, 2013).

In the literature, the relationship between public expenditure and economic growth has been discussed extensively, with controversy. Studies which include Kormendi and Meguire (1985); Aschauer (1989); Barro (1990); and Fischer (1993), among many others, have examined the effects of aggregate government spending on growth and productivity. However, Easterly and Rebelo (1993); and Devarajan, Swaroop and Zou (2006) have made a systematic examination of the relationship between the composition of public expenditures and economic growth. Also, using aggregate values, Singh and Sahni (1984); Ram (1986); and Holmes and Hutton (1990) showed that government expenditure had positive effect on economic growth. But Landau $(1983,1986)$, Barth, Keleher and Russek (1990) found a negative impact of public spending on economic growth for many developed and less-developed countries. Ram (1986) nevertheless detected a non-consistent causal relation between government expenditure and economic growth.

Specifically for Nigeria, Essien (1997); Aregbeyen (2006); Babatunde (2007); Ighodaro and Oriakhi (2010); and Oyinlola and Akinnibosun (2013), amongst others, have studied the relationship between economic growth and public expenditure. The conclusion of these studies was either public spending impacted on growth or both 
variables Granger-caused one another. But then, the income factor which necessitates government spending was not considered in the aforementioned studies. However, Odularu (2008); Adedokun (2012); and Akinlo (2012) have examined the effect of oil on growth in Nigeria without considering the interactive impact of government expenditure. Their results either revealed that oil influenced growth positively, or oil had adverse effect on the manufacturing sector. Thus, to the best of our knowledge, none of the existing studies has explicitly considered the combined average-impact of oil revenue and aggregate government expenditure on growth in Nigeria. Since oil is the mainstay of the Nigerian economy, the objective of this study is to first examine the impact of oil revenue on government spending, and second to evaluate the average effect of both oil revenue and government spending on growth in the country.

Essentially, oil revenue constitutes about 14 per cent of Nigeria's GDP and roughly 90 per cent of its income (African Economic Outlook, 2012). This points to the fact that Nigeria's economy is mono-cultural as it depends mainly on oil. According to the World Bank (2014), while the re-basing has reduced the estimate of the share of oil and gas in GDP, the oil sector still accounts for a strong majority of exports and budgetary revenues in the country. Regarding government spending, Nigeria ranked among the largest spenders across all countries in Africa, as it spends between 35 and 67 per cent of its GDP annually (see Fan, Yu \& Saurkar 2008). As such, since oil is the major driver of growth in Nigeria, the significance of this study is also premised on the future implication of relatively low or zero oil revenue on economic growth of the country. A situation of Dutch disease or resource cause is staring Nigeria in the face as history has proven that a country's natural oil reserve level could deplete to zero. Therefore, assuming Nigeria finds itself in this condition, what then happens to revenue, government spending, employment, poverty, and growth? Perhaps the time has come for Nigeria to refocus its development policy more on boosting production in the non-oil sectors.

The rest of the paper proceeds as follows: Section two presents some stylized facts on the Nigerian economy. The review of the literature is the focus of section three, while the methodological approach to the analysis of the paper is discussed in section four. Section five presents and interprets the empirical results. The conclusion and policy implications are drawn in section six.

\section{Stylized Facts on Oil Revenue, Government Spending and Economic Growth}

Nigeria is endowed with over 30 different minerals which include gold, limestone, iron ore and coal. Being resource-rich, the country has about 37.2 billion barrels of proven oil reserves, 187 trillion cubic feet of proven natural gas and produces about 2.3 million barrels of oil per day. This makes Nigeria the largest oil producer in Africa and the tenth largest in the world. Despite the statistics, the country imports about 85 per cent of its refined petroleum products due to the low capacity utilization (around 30 per cent) and frequent breakdowns of its refineries.

Over the years, Nigeria relied largely on revenue from oil to finance its budget. Following weaker prices and declining output which resulted from regional unrest, the consolidated overall budget surplus of 2008 was substantially reversed to deficit amounting to 10.4 per cent of GDP in 2009 and to about 6.8 per cent of GDP in 2010. Thus, in 2009 , about $\$ 20$ billion was utilized to finance the budget. The Nigerian economy slowed down from 7.4 per cent growth in 2011 to 6.6 per cent in 2012. During this period the oil sector continued to drive the economy, with average growth of about 8.0 per cent, compared to -0.35 per cent for the non-oil sector. By implication, the oil and gas sectors continue to dominate economic activities in Nigeria. As depicted in Figure 1, revenue from oil in the country rose from $\$ 8.35$ billion in 1980 to about 1.6 trillion in 2000, and later over the years, to over $\$ 8$ trillion in 2012. During the same period, public expenditure increased to about $\$ 4.6$ trillion in 2012 from over 1.7 trillion in 2001. As embedded in Figure 2, capital expenditure as percentage of GDP reduced from 9.3 per cent in 2001 to 2.0 per cent in 2012. 


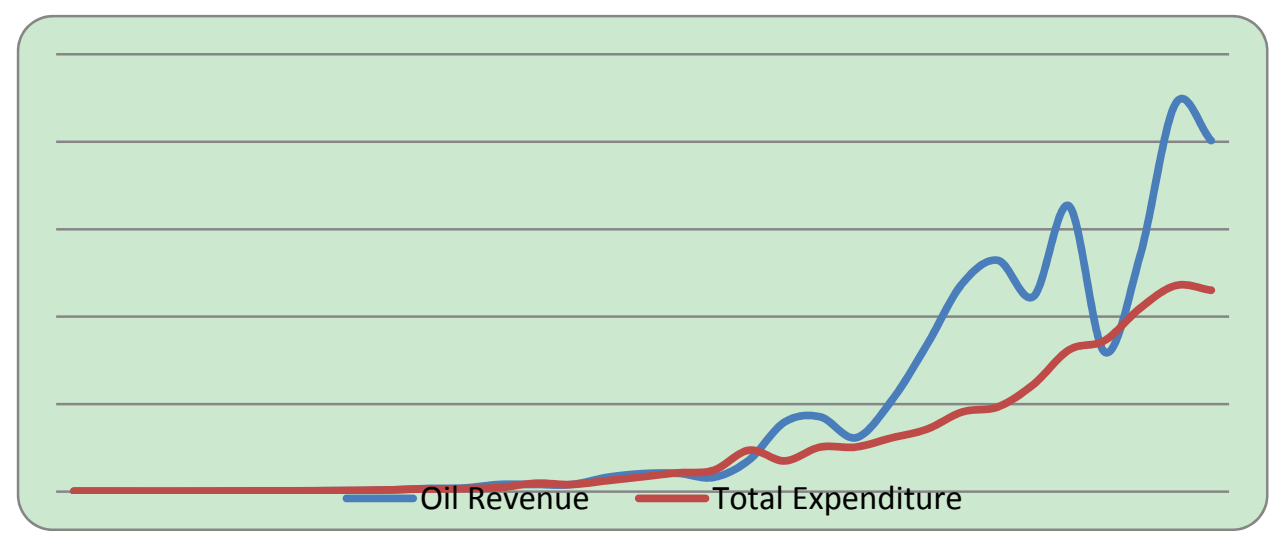

Figure 1. Trends of oil revenue and total expenditure

Source: Authors' representation using data from Central Bank of Nigeria, (2013).

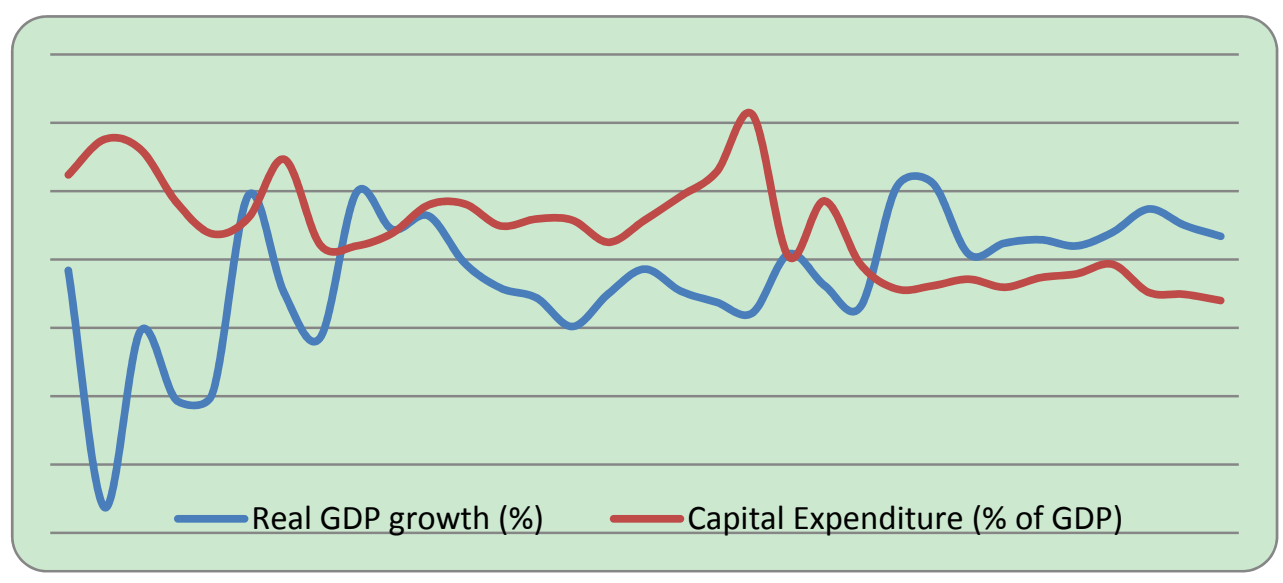

Figure 2. Trends of real GDP growth (\%) and capital expenditure as percentage of GDP

Source: Authors' representation using data from IMF, International Financial Statistics (2013).

Furthermore, the share of capital expenditure on social community services (Health, Education and other allied services) in the total rose from 10.0 per cent in 2011 to 11.1 per cent in 2012 while economic services (agriculture and infrastructures) declined from 42.1 per cent to 36.7 per cent, respectively. In consequence, the ratio of capital expenditure to total expenditure reduced from 24.3 per cent in 2012 to an estimated 23.9 per cent in 2013. It is, however, worthy of note that despite the observed persistent decline in oil revenues and total revenue throughout 2013, non-oil revenues have been rising significantly over the same period, thereby compensating marginally for the shortfall in oil revenues. In this regard, the government has resulted to expenditure adjustments in order to accommodate the revenue shortfall. Nevertheless, capital expenditure suffers huge downward adjustments because recurrent expenditures, which are mainly salaries and overhead, could hardly be adjusted automatically. Meanwhile, the downward adjustments in capital expenditure may necessarily slowdown total economic activities and growth.

\section{Literature Review}

\subsection{Review of Oil and Growth Nexus}

Observing that crude oil has been a major source of revenue, energy and foreign exchange for the Nigerian economy, Odularu (2008) analyzed the relationship between the crude oil sector and the Nigerian economic performance. Finding revealed that crude oil consumption and export have contributed to the improvement of the Nigerian economy. Thus, the study concluded that government should implement policies that would encourage active private sector participation in the crude oil sector in the country. Adedokun (2012) examined the effect of oil export revenue on economic growth in Nigeria between the period of 1975 and 2009. Empirical analysis from the study suggested that oil export revenue had a positively significant effect on growth both in the short-term 
and long-term in the country. The study further revealed that the primary determinant of foreign exchange earnings in Nigeria was changes in the world crude oil prices. Akinlo (2012) assessed the importance of oil in the development of the Nigerian economy over the period 1960 to 2009. Empirical evidence showed that oil could cause other non-oil sectors to grow. However, oil had adverse effect on the manufacturing sector. Findings revealed bidirectional causality between oil and manufacturing, oil and building and construction, manufacturing and building, and construction, manufacturing and trade and services, and agriculture and building and construction. It also confirmed unidirectional causality from manufacturing to agriculture, and trade and services to oil. However, the paper found no causality between agriculture and oil, likewise between trade and services and building and construction. In conclusion, the study recommended appropriate regulatory and pricing reforms in the oil sector in order to integrate it into the economy, and as well reverse the negative impact of oil on the manufacturing sub sector in Nigeria. Oladipo and Fabayo (2012) investigated global recession and the oil sector, based on its effects on economic growth in Nigeria. Analysis from the study revealed a negatively significant relationship between GDP and oil produced (domestic consumption and export) in the country. The result also showed the existence of a decline in the oil sector due to global recession. The study, therefore, recommended deregulation of the oil sector for efficient performance, and more rigorous policies that will reduce global effects on the sector as it contributes the largest percentage of income to the Nigerian economy.

In Iran, Farzanegan (2011) analyzed the dynamic effects of oil shocks on different categories of the Iranian government expenditures from 1959 to 2007. The main results showed that Iran's military and security expenditures significantly responded to a shock in oil revenues (or oil prices), while social spending components did not show significant reactions to such shocks. Kablan, Loening and Tanaka (2014) examined whether Chad was affected by Dutch disease by first analyzing if Chad's economy presented some features that supported the existence of the natural resource curse, such as volatility in government resources, poor institutions, recurrent tensions, and mismanagement of oil resources. The results suggested that changes in domestic output and prices were determined by aggregate demand and supply shocks. However, findings showed that oil production and high international prices negatively affected agricultural output by small proportion. While associating the findings with structural underemployment and the inefficient use of existing production factor, the study concluded that increased public expenditures in tradable sectors present the opportunity to make oil revenues an engine of national development.

\subsection{Review of Government Spending and Growth Nexus}

Cheng and Lai (1997) examined the causality between government expenditure and economic growth along with money supply in a trivariate framework over the period 1954 to 1994 in South Korea. In consistence with some of the previous studies that detected a feedback between GDP and expenditure, the study found bidirectional causality between government expenditures and economic growth in the country. Result of the study also suggested that money supply affected economic growth in South Korea. Fölster and Henrekson (2001) examined the growth effects of government expenditure and taxation in a sample of rich countries over the period between 1970 and 1995. The general finding of the study was that the more econometric problems that were addressed, the more robust the relationship between government size and economic growth appeared. Gong and Zou (2002) set up a theoretical model linking the growth rate of the economy to the growth rate and volatility of different government expenditures. On the theoretical front, the study found that, depending on the intertemporal elasticity in consumption, volatility in government spending can positively or negatively be associated with economic growth. Empirically, however, the study revealed a no-relationship between growth in capital expenditure and output growth, whereas growth in current expenditure seemed to drive output growth. AlBataineh (2012) investigated the impact of government expenditures on economic growth in Jordan during the period 1990 to 2010. Results from the study suggested that government expenditure at the aggregate level had positive impact on the growth of GDP in compatibility with the Keynesians theory. Also, the result showed that payment had no influence on GDP growth. Contributing to the empirical literature on the debate about the validity of the Wagner's hypothesis, Salih (2012) tested the hypothesis in the context of Sudan for the period 1970-2010. The results clearly supported the Wagner hypothesis as the growth of per capita real GDP had unidirectional relationship with the share of government spending to GDP. Thus, the study concluded that the Keynesian theory which states that increases in government spending result in increases in GDP was not supported by the data from Sudan. Alshahrani and Alsadiq (2014) empirically examined the effects of different types of government expenditures on economic growth in Saudi Arabia over the period from 1969 to 2010. Findings from the study indicated that while private domestic and public investments, as well as healthcare expenditure, stimulated growth in the long-run, openness to trade and spending in the housing sector could also boost short-run production. 
Meanwhile, studies that had in different periods examined the nexus between government spending and economic growth in Nigeria are vast in the empirical literature. For example, Oyinlola (1993) reported a positive impact of defence expenditure on economic growth. Also, Ogiogio (1995) revealed a long-term relationship between government expenditure and economic growth and also discovered that recurrent expenditure exerted more influence, than capital expenditure, on growth. Furthermore, Fajingbesi and Odusola (1999) observed that real government capital expenditure had a significant positive effect on real output and that real government recurrent expenditure influenced growth only mildly in the country. However, Akpan (2005) concluded that there was no significant relation between most components of government expenditure and economic growth in Nigeria. While employing a model that specified the effect of government consumption, investment spending, and private investment on real gross domestic product, Maku (2009) investigated the link between government spending and economic growth in Nigeria. The study found that private and public investments had insignificant effect on economic growth during the review period. Ighodaro and Oriakhi (2010) found that increase in total government expenditure as well as specific expenditure on general administration and social services propelled economic growth. Adeniyi and Bashir (2011) found that government spending on agriculture, education, defense and internal security services as well as structural adjustment programme was significant factor that influenced economic growth in the country. Usman et al (2011) investigated the effect of federal government expenditure on economic growth in Nigeria. Results of the study showed that in the short run public spending had no impact on growth, but in the long run, a relationship was established between the two variables. Oyinlola and Akinnibosun (2013) examined the relationship between public expenditure and economic growth in Nigeria during the period 1970-2009. After confirming the Wagner's law, the result of the study further showed that economic growth and development were the main objectives of government expenditure, especially investment in infrastructure and human resources all of which fall under social and community services. Essentially, Nurudeen and Usman (2010) showed that total capital expenditure, total recurrent expenditure, and government expenditure on education had negative effect on economic growth. Government expenditure on transport and communication, and health, however, had positive impact on economic growth. In corroboration, Adewara and Oloni (2012) explored the relationship between the composition of public expenditure and economic growth in Nigeria between 1960 and 2008. The study found that expenditure on education failed to enhance economic growth while expenditure on health and agriculture contributed positively to growth. Also, in a related study, Kolawole, Omobitan and Yaqub (2015) found a significant positive association between government expenditure on health and per capita growth in Nigeria, as against significant negative impact of government expenditure on education on per capita GDP over the period between 1980 and 2012 in the country.

\subsection{Review of Oil Revenue, Government Spending and Growth Nexus}

Hamdi and Sbia (2013) empirically examined the dynamic relationships among oil revenues, government spending and economic growth in the Kingdom of Bahrain over the period from 1960 to 2010. The study investigated whether the huge government spending enhanced the pace of economic growth or not. Overall results suggested that oil revenues remained the principal source for growth, and the main channel which financed government spending.

\section{Methodology}

The ordinary least square (OLS) technique was adopted in this study. However, in the attempt to establish the government spending-oil revenue-growth nexus in the Nigerian economy, two separate linear equations were estimated. The first examined the causality between oil revenue and government spending, while the second evaluated the effects of oil revenue and government spending on growth. Since the evaluation considered both the short- and long-run simultaneously, the econometric methodology of the Vector Error Correction Mechanism (VECM) was also employed. In order to undertake the empirical analysis using the VECM technique, the variables involved in the model must be non-stationary and integrated of the same order, or they should be stationary (see Nelson \& Polser 1982; Stock \& Watson 1988; and Campbell \& Perron 1991). Thus both the Augmented Dickey-Fuller (ADF) (Dickey \& Fuller, 1979, 1981) and Phillips-Perron (PP) (1988) unit root tests were utilized to test for the order of integration of the variables. In the process of testing for cointegration, two separate methods were used. First, the presence of unit roots in the residuals from the regressions of variables in levels was tested. Then, the Johansen (1988) and Johansen and Juselius (1990) full information maximum likelihood of a VECM Model was utilized. Furthermore, the pairwise causality between the variables, known as Granger causality test (see Granger 1969, 1988) was carried out using the required three steps: the analysis of the time series in order to determine the order of integration; examining the long run equilibrium relationship between the two variables; and investigation of the short run and the long run causality relationship between each pair of the variables. 
Annual data covering the period from 1980 to 2012 were employed. Total government expenditure, oil revenue and real GDP were the variables of interest. Essentially, for the reason of uniformity in measurement, and clarity in the interpretation of findings, the variables were transformed to their natural logarithms to eliminate any serial correlation that might be present and were denoted by $\operatorname{lnGsp}$, lnOrev, and lnGdp. Data on total expenditure and oil revenue were obtained from the statistical bulletin of the Central Bank of Nigeria (CBN) (2013), while data for the real GDP were collated from the international financial statistics of the International Monetary Fund (IMF) (2013).

\subsection{The Model}

The relationship among oil revenue, public spending and economic growth in Nigeria was represented, following Ram (1986, 1988), and Al-Qudair (2005), in the modified expressions in (1) and (2) below as follows.

$$
\begin{aligned}
& \operatorname{lnGsp_{t}}=\alpha_{0}+\alpha_{1} \operatorname{lnOrev}_{t}+\varepsilon_{t} \\
& \operatorname{lnGdp_{t}}=\beta_{0}+\beta_{1} \operatorname{lnOrev}_{t}+\beta_{2} \operatorname{lnGsp_{t}}+\mu_{t}
\end{aligned}
$$

where $\mathrm{t}$ signifies time, $\alpha_{i}$ and $\beta_{i}$ are coefficients, $\varepsilon$ and $\mu$ are the respective error terms. Others are as earlier defined above. The apriori expectation is that a positive relationship would be established between growth and each of oil revenue and government spending.

\section{Empirical Results and Discussion}

\subsection{Stationarity and Cointegration Results}

As a first step, the stationarity of the variables was tested by conducting the Augmented Dickey-Fuller (ADF) and Phillips-Perron (PP) unit root tests. The results, as presented in Table 1 showed strong evidence(s) that all the variables were integrated of order one, that is, I(1). The next step was to test for the presence of long-run relation among the variables, that is, cointegrating relationships. Table 2 and Table 3 show the results of the cointegration tests which suggested three, and at least one cointegration equation at the 5 percent level of significance.

Table 1. Augmented Dickey-Fuller and Phillips-Perron unit root test

\begin{tabular}{lccccc}
\hline Variable & Stage & Critical Value & $1 \%$ & $5 \%$ & $10 \%$ \\
\hline LnGdp & 1st Difference & -5.964880 & -2.664853 & -1.955681 & -1.608793 \\
LnOrev & 1st Difference & -9.356430 & -3.724070 & -2.986225 & -2.632604 \\
LnGsp & 1st Difference & -8.113853 & -2.647120 & -1.952910 & -1.610011 \\
\hline
\end{tabular}

Table 2. Result of the Johansen cointegration rank test (Trace)

\begin{tabular}{lcccc}
\hline Hyp. No. & Eigenvalue & Trace Stat & 5\% C.V. & Prob. \\
\hline $\mathrm{r}=0$ & 0.500719 & 44.15919 & 29.79707 & 0.0006 \\
$\mathrm{r} \leq 1$ & 0.367707 & 22.62704 & 15.49471 & 0.0036 \\
$\mathrm{r} \leq 2$ & 0.237766 & 8.416555 & 3.841466 & 0.0037 \\
\hline
\end{tabular}

Source: Authors' computation

Table 3. Result of the Johansen cointegration rank test (Maximum Eigenvalue)

\begin{tabular}{ccccc}
\hline Hyp. No. & Eigenvalue & Max-Eigen Stat & 5\% C.V. & Prob. \\
\hline $\mathrm{r}=0$ & 0.500719 & 21.53215 & 21.13162 & 0.0439 \\
$\mathrm{r} \leq 1$ & 0.367707 & 14.21048 & 14.26460 & 0.0510 \\
$\mathrm{r} \leq 2$ & 0.237766 & 8.416555 & 3.841466 & 0.0037 \\
\hline
\end{tabular}

Source: Authors' computation 


\subsection{Granger Causality and ECM Results}

As presented in Table 4, the causality relationship between growth and government was bidirectional as both variables Granger caused each other. Oil revenue, however, had a unidirectional relationship with each of growth and government spending. Specifically, the results revealed that oil revenue Granger caused growth at 5 per cent level of significance as against Granger causing government spending at 1 per cent level of significance. Since Granger test is sensitive to the number of lags of the explanatory variables included in the causality equations, the Information Criterion (AIC) (Akaike, 1969), amongst others, was used to choose the optimal lags as presented in Table 5.

Table 4. Pairwise Granger causality test result

\begin{tabular}{lccc}
\hline Null Hypothesis & F-statistic & Probability & Decision \\
\hline Orev does not Granger cause Gdp & 5.30894 & 0.0117 & Reject \\
Gdp does not Granger cause Orev & 0.57336 & 0.5706 & Accept \\
Gsp does not Granger cause Gdp & 1.01595 & 0.3760 & Accept \\
Gdp does not Granger cause Gsp & 0.37681 & 0.6897 & Accept \\
Gsp does not Granger cause Orev & 0.89043 & 0.4226 & Accept \\
Orev does not Granger cause Gsp & 6.85288 & 0.0041 & Reject \\
\hline
\end{tabular}

Source: Authors' computation.

Table 5. Lag length selection criteria

\begin{tabular}{lcccccc}
\hline \multicolumn{6}{l}{ Endogenous variables: LNOREV LNGSP } & \multicolumn{5}{l}{} \\
\hline Lag & LogL & LR & FPE & AIC & SC & HQ \\
0 & -1021.66 & NA & $1.70 \mathrm{E}+15$ & 74.34657 & 71.34657 & $71.13608^{*}$ \\
1 & -1080.15 & $62.65413^{*}$ & $1.21 \mathrm{e}+15^{*}$ & 73.79976 & 72.67045 & 71.32632 \\
2 & -1053.77 & 29.90087 & $3.41 \mathrm{E}+25$ & $74.34989^{*}$ & $78.08366^{*}$ & 72.20246 \\
\hline
\end{tabular}

Source: Authors' computation.

The estimated coefficient of the error correction term, ECT(-1) which is also the speed of adjustment to equilibrium, was negative and statistically significant as required by the Granger representation theorem. This, as shown in Table 6, implied the validity of the long run relationship between each pair of the variables. The speed of adjustment to equilibrium required 83 per cent within a year when the variables drifted away from their equilibrium values. Thus, it provided enough evidence that GDP and Gsp; Gdp and Orev; as well as Orev and Gsp were cointegrated over the period considered. In addition, the ECM result revealed that oil revenue and government spending drove economic growth positively at 5 per cent and 10 per cent level of significance, respectively. This implied that a hundred percentage point increase in oil revenue, as well as in government spending caused a rise in growth of about 38 per cent and 3 per cent, respectively.

Table 6. Error correction model (ECM)

\begin{tabular}{lcccc}
\hline Dependent Variable: D(LNGDP) & & & \\
\hline Variable & Coefficient & Std. Error & t. Statistic & Prob. \\
D(LNORV) & 0.38669 & 0.089668 & 2.08676 & 0.0231 \\
D(LNTXP) & 0.03215 & 0.072754 & 1.95755 & 0.0779 \\
ECT(-1) & -0.83224 & 0.192676 & -3.37518 & 0.0036 \\
\hline Adj. $\mathrm{R}^{2}: 0.501142$ & DW: 1.773328 & & & \\
\hline
\end{tabular}

Source: Authors' computation 


\section{Conclusion and Policy Implication}

This study has examined the relationships among oil revenue, government spending, and economic growth in Nigeria. Specifically, it investigated if oil revenue impacted on government spending, as well as on economic growth in the country over the period 1980 to 2012. Econometric techniques which included OLS, VECM, cointegration and Granger causality were employed to determine the direction of causality and the magnitude of impacts. Findings from the analysis revealed that oil revenue Granger caused total government spending, while there was no causality between government spending and growth. Also, it was revealed that oil revenue Granger caused as well as impacted positively on economic growth. It was therefore concluded that oil revenue has been a very important variable that propelled government spending and economic growth in Nigeria.

The foregoing findings bear some implications for policy formulation. Firstly, given no-causality between government spending and growth, even though a mild impact of the former on the latter was reported, the government needs to re-examine the shares of both capital and recurrent expenditure in total government spending. Over the years, the percentage of recurrent expenditure has over-blotted to the extent that more than 70 per cent of the country's budget was allocated to this item at the expense of capital spending. A situation of such can only bring about a mild nominal non-inclusive growth which has been the experience over the years. Therefore, government should boost spending on capital or developmental projects. By doing this, jobs would be created, the economy would grow and poverty would decline.

Secondly, because government spending and economic growth were Granger caused and largely influenced by revenue from oil, it follows therefore that government should intensify efforts at increasing output in the oil sub-sector. In doing so, revenue would improve and more funds would be available for spending, and growth. It must, however be burn in mind that while trying to boost production of oil, government must not over-concentrate on the oil sub-sector by shifting interest from the non-oil sector in the country. This is important because of the fact that experience has shown that natural oil reserve level could deplete to zero. A situation of zero oil reserve implies a zero production as well as zero revenue from oil. Therefore, assuming Nigeria finds itself in this condition, what then happens to government spending, employment, poverty, and growth? The best way out of this imminent threat is that as efforts at boosting oil production and revenue are being intensified, the government should also devote significant resources to developing the non-oil sector. Substantial resources should be made available to the agriculture sector where cash crops produce like rubber, cocoa, palm oil and kernel, ground nut, cola nuts, and so forth could be largely produced for export, and local consumption. Also, the manufacturing sub-sector should be provided with resources like electricity, road infrastructure, long- and medium-term credit facilities, and enabling business environment in order to boost production for export, and possibly help in the manufacture of some goods that are presently imported. If the government does this it would broaden the revenue base, and assist in stabilizing the economy in the period when revenue from oil drops as a result of resource depletion or decline in the international price of oil as currently being experienced.

\section{References}

Adedokun, A. J. (2012). Oil Export and Economic Growth: Descriptive Analysis and Empirical Evidence from Nigeria. Pakistan Journal of Social Sciences, 9(1), 46-58. http://dx.doi.org/10.3923/pjssci.2012.46.58

Adeniyi, O. M., \& Bashir, A. O. (2011). Sectoral Analysis of the Impact of Public Investment on Economic Growth in Nigeria (1970-2008). European Journal of Social Sciences, 20(2), 259.

Adewara, S. O., \& Oloni, E. F. (2012). Composition of Public Expenditure and Economic Growth in Nigeria. Journal of Emerging Trends in Economic Management Science, 3(4), 403-407.

African Economic Outlook (2012). Nigeria. www.africaneconomicoutlook.org

Akaike, H. (1969). Fitting Autoregressive Models for Prediction. Annals of the Institute of Statistical Mathematics, 21, 243-247. http://dx.doi.org/10.1007/BF02532251

Akinlo, A. E. (2012). How Important is Oil in Nigeria's Economic Growth? Journal of Sustainable Development, 5, 165-179. http://dx.doi.org/10.5539/jsd.v5n4p165

Akpan, N. I. (2005). Government Expenditure and Economic Growth in Nigeria: A disaggregated Approach. CBN Economic and Financial Review, 43(1), 51-69.

Al-Bataineh, I. M. (2012). The Impact of Government Expenditures on Economic Growth in Jordan. Interdisciplinary Journal of Contemporary Research in Business, 4(6), 1320-1338.

Al-Qudair, K. H. A. (2005). The Relationship between Government Expenditure and Revenues in the Kingdom of Saudi Arabia: Testing for Cointegration and Causality. JKAU: Economics and Administration, 19(1), 
31-43. http://dx.doi.org/10.4197/eco.19-1.2

Alshahrani, S., \& Alsadiq, A. (2014). Economic Growth and Government Spending in Saudi Arabia: An Empirical Investigation. IMF Working Paper WP/14/3. http://dx.doi.org/10.5089/9781484348796.001

Aregbeyen, O. (2006). Cointegration, Causality and Wagner's law: A Test for Nigeria. CBN Economic and Financial Review, 44(2), 1-7.

Aschauer, D. (1989). Is Government Spending Productive? Journal of Monetary Economics, 23, 177-200. http://dx.doi.org/10.1016/0304-3932(89)90047-0

Babatunde, M. A. (2007). A Bound Testing Analysis of Wagner's law in Nigeria: 1970-2006. Applied Economics, $1-8$.

Barro, R. (1990). Government Spending in a Simple Model of Endogenous Growth. Journal of Political Economy, 98, 103-125. http://dx.doi.org/10.1086/261726

Barth, J. R., Keleher, R. E., \& Russek, F. S. (1990). The Scale of Government and Economic Activity. Southern Economic Journal, 13, 142-183.

Cameron, D.R. (1978). 'The Expansion of the Public Economy: A Comparative Analysis'. American Political Science Review, 72(4), 1243-1261. http://dx.doi.org/10.2307/1954537

Campbell, J. Y., \& Perron, P. (1991). Pitfalls and Opportunities: What Macroeconomists Should Know about Unit Roots. In O. J. Blanchard, \& S. Fischer (Eds.), NBER Macroeconomics Annual (pp. 141-201). MIT Press, Cambridge, MA 14. http://dx.doi.org/10.2307/3585053

Central Bank of Nigeria. (2013). Statistical Bulletin. Retrieved from http://www.cbn.gov.ng

Cheng, B. S., \& Lai, T. W. (1997). Government Expenditures and Economic Growth in South Korea: A VAR Approach. Journal of Economic Development, 22(1), 11-24.

Devarajan, S., Swaroop, V., \& Zou, H. (2006). The Composition of Public Expenditure and Economic Growth. Journal of Monetary Economics, 37, 313-344. http://dx.doi.org/10.1016/S0304-3932(96)90039-2

Dickey, D. A., \& Fuller, W. A. (1979). Distribution of the Estimators for Autoregressive Time Series with a Unit Root. Journal of the American Statistical Association, 74, 427-431.

Dickey, D. A., \& Fuller, W. A. (1981). Likelihood Ratio Statistics for Autoregressive Time Series with a Unit Root. Econometrica, 49, 1057-1072. http://dx.doi.org/10.2307/1912517

Easterly, W., \& Rebelo, S. (1993). Fiscal Policy and Economic growth: An Empirical Investigation. Journal of Monetary Economics, 32, 417-458. http://dx.doi.org/10.1016/0304-3932(93)90025-B

Essien, E. A. (1997). Public Sector Growth: An Econometric Test of Wagner's Law. Central Bank of Nigeria. Economic and Financial Review, 35, 3.

Fajingbesi, A. A., \& Odusola, A. F. (1999). Public Expenditure and Growth. A Paper presented at a Training Programme on Fiscal Policy Planning Management in Nigeria, Organized by NCEMA, Ibadan, Oyo State. pp. 137-179.

Fan, S., Yu, B., \& Saurkar, A. (2008). Public Spending in Developing Countries: Trends, Determination, and Impact. In S. Fan (Ed.), Public Expenditures, Growth, and Poverty Lessons from Developing Countries (pp. 20-55).

Farzanegan, M. R. (2011). Oil Revenue Shocks and Government Spending Behaviour in Iran. Energy Economics, 33(6), 1055-1069. http://dx.doi.org/10.1016/j.eneco.2011.05.005

Fischer, S. (1993). The Role of Macroeconomic Factors in Economic Growth. Journal of Monetary Economics, 32, 485-512. http://dx.doi.org/10.1016/0304-3932(93)90027-D

Fölster, S., \& Henrekson, M. (2001). Growth Effects of Government Expenditure and Taxation in Rich Countries. European Economic Review, 45(8). http://dx.doi.org/10.1016/S0014-2921(00)00083-0

Gong, L. T., \& Zou, H. F. (2002). Effects of Growth and Volatility in Public Expenditures on Economic Growth: Theory and Evidence. Annals of Economics and Finance, 3, 379-406.

Granger, C. W. J. (1969). Investigating Causal Relations by Econometric Models and Cross- Spectral Methods. Econometrica, 37, 242-238. http://dx.doi.org/10.2307/1912791

Granger, C. W. (1988). Some Recent Development in a Concept of Causality. Journal of Econometrics, 39, 199-211. http://dx.doi.org/10.1016/0304-4076(88)90045-0 
Hamdi, H., \& Sbia, R. (2013). Dynamic relationships between oil revenues, government spending and economic growth in an oil-dependent economy. Economic Modelling, 35(C), 118-125. http://dx.doi.org/10.1016/j.econmod.2013.06.043

Holmes, J. M. \& Hutton, P.A. (1990). “On the Causal Relationship Between Government Expenditures and National Income.” Review of Economics and Statistics, 72, pp. 87-95. http://dx.doi.org/10.2307/2109743

Ighodaro, C. A. U., \& Oriakhi, D. E. (2010). Does the Relationship between Government Expenditure and Economic Growth follow Wagner's Law in Nigeria? Annals of the University of Petrosani, Economics, 10(2), 185-198.

International Monetary Fund. (2013). International Financial Statistics.

Johansen, S. (1988). Statistical Analysis of Cointegration Vectors. Journal of Economics, Dynamics and Control, 12, 231-254. http://dx.doi.org/10.1016/0165-1889(88)90041-3

Johansen, S., \& Juselius, K. (1990). Maximum Likelihood Estimation and Interference on Cointegration with Application to the Demand for Money. Oxford Bulletin of Economics and Statistics, 52, 169-210. http://dx.doi.org/10.1111/j.1468-0084.1990.mp52002003.x

Kablan, S., Loening, L., \& Tanaka, Y. (2014). Is Chad Affected by Dutch or Nigerian Disease? Journal of Empirical Economics, 3(5), 278-295.

Kolawole, B. O., Omobitan, O. A., \& Yaqub, J. O. (2015). Poverty, Inequality and Rising Growth in Nigeria: Further Empirical Evidence. International Journal of Economics and Finance, 7(2), 51-62. http://dx.doi.org/10.5539/ijef.v7n2p51

Kormendi, R. C., \& Meguire, P. G. (1985). Macroeconomic Determinants of Growth: Cross Country Evidence. Journal of Monetary Economics, 16(2), 141-63. http://dx.doi.org/10.1016/0304-3932

Landau, D. (1983). Government Expenditure and Economic Growth: A Cross-Country Study. Southern Economic Journal, 49, 783-792. http://dx.doi.org/10.2307/1058716

Landau, D. (1986). Government Expenditure and Growth in Less Developed Countries: An Empirical Study for 1960-1980. Economic Development and Cultural Change, 35, 35-75. http://dx.doi.org/10.1086/451572

Maku, O. E. (2009). Does Government Spending Spur Economic Growth in Nigeria? MPRA Paper No. 17941.

Nelson, C., \& Plosser, C. (1982). Trends and Random Walks in Macroeconomic Time Series; Some Evidence and Implications. Journal of Money Economics, $139-162$. http://dx.doi.org/10.1016/0304-3932(82)90012-5

Nurudeen, A., \& Usman, A. (2010). Government Expenditure and Economic Growth in Nigeria, 1970-2008: A Disaggregated Analysis. Business Economics Journal, 4, 1-11.

Odularu, G. O. (2008). Crude Oil and the Nigerian Economic Performance. Oil and Gas Business. Retrieved from http://www.ogbus.ru/eng/

Ogiogio, G. O. (1995). Government Expenditure and Economic Growth in Nigeria. Journal of Economic Management, 2(1), 1.

Oladipo, S. O., \& Fabayo, J. O. (2012). Global Recession, Oil Sector and Economic Growth in Nigeria. Asian Transactions on Basic and Applied Sciences, 1(6), 29-41.

Oyinlola, M. A., \& Akinnibosun, O. (2013). Public Expenditure and Economic Growth Nexus: Further Evidence from Nigeria. Journal of Economics and International Finance, 5(4), 146-154. http://dx.doi.org/10.5897/JEIF2013.0489

Oyinlola, O. (1993). Nigeria's National Defense and Economic Development: An Impact Analysis. Scandinavian Journal of Development Alternatives, 12(3), 241-253.

Phillips, P. C. B., \& Perron, P. (1988). Testing for a Unit Root in Time Series Regression. Biometrika, 75, 335-346. http://dx.doi.org/10.1093/biomet/75.2.335

Ram, R. (1986). Government Size and Economic Growth: A New Framework and some Evidence from Cross-Section and Time Series Data. America Economic Review, 76, 191-203.

Ram, R. (1988). Additional Evidence on Causality between Government Revenue and Government Expenditure. Southern Economic Journal, 58, 763-769. http://dx.doi.org/10.2307/1059018

Salih, M. A. R. (2012). The Relationship between Economic Growth and Government Expenditure: Evidence 
from Sudan. International Business Research, 5(8), 40-46. http://dx.doi.org/10.5539/ibr.v5n8p40

Singh, B., \& Shani, B. S. (1984). Causality between Public Expenditure and National Income. Review of Economic Statistics, 66(4), 630-644. http://dx.doi.org/10.2307/1935987

Stock, J.H. \& Watson, M.W. (1988). Variable Trends in Economic Time Series. The Journal of Economic Perspectives, 2(3), 147-174. http://dx.doi.org/10.1257/jep.2.3.147

The World Bank. (2014). Nigeria Economic Report. www.worldbank.org/data

Usman, A., Mobolaji, H. I., Kilishi, A. A., Yaru, M. A., \& Yakubu, T. A. (2011). Public Expenditure and Economic Growth in Nigeria. Asian Economic and Financial Review, 1(3), 104-113.

\section{Copyrights}

Copyright for this article is retained by the author(s), with first publication rights granted to the journal.

This is an open-access article distributed under the terms and conditions of the Creative Commons Attribution license (http://creativecommons.org/licenses/by/3.0/). 